of the earth accessible to man. The rate of use of some of these metals is doubling each decade. We still use tin-foil for wrapping up sweets and cigarettes. At the present mining rates, iron will be exhausted in Germany in about fifty years and in the United States in about a hundred years. The supply of sulphur in the United States will fail in fifteen years, the coal of Germany in less than a thousand years and of the United States, notwithstanding its huge lignite deposits, in less than fifteen hundred years. It looks as if the machine age may starve to death before long, a victim of to-day's profligate use of metals, coal and oil. Water power, alcohol from vegetation, solar energy, etc., are at present totally inadequate to replace oil and coal. Will future civilisations look back upon the industrial civilisation of the twentieth century as an age of robbery?

\section{U.S. Bureau of Standards}

THE annual report of the Director of the Bureau of Standards (Government Printing Office, Washington, 1932) shows the trend of scientific developments during last year. The increase in the industrial applications of very low temperatures has made it advisable to extend the scale downwards from $-100^{\circ} \mathrm{C}$. to $-259^{\circ} \mathrm{C}$. and a temporary scale covering this range has been established. Fire tests have been made on the new welded steel floors which are now being used in buildings. They consist of steel floor plates welded to beams spaced two feet apart. Tests were made with fire both above and below the floor. Gas appliances found quite satisfactory at sea level develop defects when used in cities at high altitudes. The causes of these defects are being investigated. Perhaps the most spectacular advance made during the year has been to increase the accuracy of the primary frequency standard to one part in ten million. Regular transmissions of standard highfrequency waves at a frequency of 5,000 kilocycles per second are broadcast every Tuesday for four hours. The accuracy obtained is one cycle per second, that is, one part in five million. The ionised layer in the atmosphere has been determined to be the major controlling factor in the long distance transmission of radio waves. The measurement of the height of this layer is of primary importance in interpreting transmission conditions and increasing our knowledge of radio wave transmission. Using improved equipment, these measurements were made on one day in each week throughout the year. An automatic recorder is now in use which makes continuous measurements. Useful work is done in making careful analyses of samples of ores, alloys, pure metals, cement and pure chemicals. These samples are sold to industrial laboratories and are used for checking their own methods and results. This plan has contributed greatly to the precision of the analytical work in these laboratories and the project is self-supporting.

\section{Miners' Nystagmus}

Two reports on this subject by a Committee of the Medical Research Council were issued in 1922 and
1923. The principal finding of the Committee was that the chief symptom of this disease-the involuntary oscillation of the eyeballs-is caused by an insufficiency of the light reaching the eyes of the miner while at work, and that the most important measure of prevention is to secure for the miner at work adequate illumination. Nevertheless, in spite of considerable improvement in the illumination of mines, the incidence of the disease has, on the whole, steadily increased, for compensation on account of this disability was paid to 10,638 persons in 1930 ; this is the largest number, with one exception, during the past twenty-three years. The Medical Research Council has therefore considered it advisable to reconstitute the Committee, which has now issued a third report on the subject (Special Rep. Series, No. 176. H.M. Stationery Office. 9d.). This reaffirms, in the strongest terms, the conclusions of the former committee. There should be constant illumination of 0.25 foot-candle on the coal face, and it is understood that there are recent developments in the direction of improving illumination in mines. To account for the continued prevalence of the condition, it must be recognised that the oscillation of the eye. balls is but a part of the disease, and various psychoses and neuroses are also present. The practical treatment of the disease should consist in the elimination of a hopeless dependence on compensation by the provision of opportunities for work of some kind, even if restoration of full work underground has to be preceded by a period of work in dayljght.

\section{Guard Posts for Road Island Refuges}

ILLUMiNATED guard posts or 'bollards' are now gradually coming into use on all types of roads which carry fast vehicular traffic. In the Osram G.E.C. Bulletin for February, a description is given of a well-designed guard post which should prove useful not only by indicating the refuge to pedestrians, thus prompting them to cross the road at that point, but also to motorists; thus removing a frequent cause of accidents. It is a luminous pillar $4 \mathrm{ft}$. high, the light being emitted only from the side which faces the traffic. The back of the pillar is made of solid steel tube, so that in the event of a smash the damage done will be probably much less than if it were made of cast iron. The head of the bollard is arranged as a lantern with the red glass fixed around half its circumference. The red glass is generally illuminated by a sixty-watt lamp but sometimes a small auxiliary lamp is used as well so as to prevent a complete 'black out' if the main lamp is extinguished. Complete isolation of the bollard from the electric supply in the event of damage is easily obtained by opening a door near the ground level where the time-switch and fuses are fixed.

\section{Researches on Sedimentation}

The report of the Committee on Sedimentation for the two years 1930-1932 has been published under the auspices of the Division of Geology and Geography of the U.S. National Research Council as National Research Bulletin No. 89, 1932 (pp. 229, price 
1 dollar). The report is by the chairman, Prof. W. H. Twenhofel, who contributes a general introduction, and various committee members and others, who are responsible for many valuable records of original research and abstracts of literature on the accessory minerals of igneous and sedimentary rocks. Special attention deserves to be given to the paper on the classification and terminology of the pyroclastic rocks by C. K. Wentworth and Howel Williams. The Bulletin also includes papers on recent advances in the study of peat; recent marine sediments; settling of bentonite in water ; relation of the buffer mechanism of sea water to the solubility of calcium carbonate; modern marine sediments in California; bacterial and chemical factors in lime deposition at Tortugas, Florida ; varved sediments ; chert and flint, concretions, and cone-in-cone; abrasional work of river ice and of glaciers; ground water hydrology in its bearing on sedimentation; rôle of micro-organisms in sediments; accessory minerals of crystalline rocks; and glacial sediments. In addition, there are summaries of work on sedimentation carried out at Stanford University, and also of recent work by German and British investigators; and abstracts of the literature on accessory minerals of igneous rocks and of sedimentary rocks.

\section{Developments in Market Gardening}

THE report of the recent conference on "Recent Developments in Market Gardening" held at Rothamsted contains a great deal of information which is not readily available in a collected form. Two of the classical market garden areas, the Bedfordshire early potato and brussels sprouts district and the equally well-known spring cabbage, brussels sprouts and fruit area of Evesham are treated in detail from the point of view of the practical grower, and the subject is also considered from the point of view of the canner, whose part in the industry is becoming increasingly important. In recent years market gardeners have found their province invaded by large-scale farmers, who have in part substituted vegetable growing for the less profitable crops of their ordinary rotation. These men, whose methods form the subject of one of the papers, have several advantages not possessed by the smaller cultivators; plentiful animal manures, large-scale mechanical methods, and a possibility of converting unsaleable surplus into live stock products. The reply of the genuine market gardener has been to move towards greater intensification, and to retire into districts as yet inaccessible to large-scale methods. The conference as a whole leaves the impression that abundant production of market garden crops is relatively easy to secure. It can in fact be an embarrassment, and every additional outlet whether by preservation, more economical distribution, or the education of the public taste, needs careful investigation. Copies of the report, price $2 s$., can be obtained from the Secretary, Rothamsted Experimental Station, Harpenden, Herts.

\section{Institute of Industrial Administration}

IN a pamphlet recently issued by the Institute of Industrial Administration, 47 King William Street,
E.C.4, outlining its objects and examinations, it is stated that management in industry is essentially the exercise of administrative function and involves the control and co-ordination of the technical functions. The operation of the administrative function does nut vary greatly from one industry to another despite differences in the application of some of the technical functions, especially that of production. It is admitted that personality is a highly significant factor in industrial administration but training serves both to develop and inform personality. To the average individual upon whom industry has mainly to rely, training may make all the difference in his efficiency, to his own advantage and that of the nation. In preparing a revised syllabus of examinations, the Institute has endeavoured to collate the principles and practice bearing on the functional aspects of industrial administration. The scheme consists of three stages-fundamentals, intermediate and final - the first of which presents in elementary form a general idea of how an industrial undertaking is conducted and its relation to external affairs. In the intermediate and final stages the subjects of the fundamental stage are extended and amplified.

\section{Physics at Harvard}

VoL. 21 of Contributions from the Physical Laboratories of Harvard University consists of separate copies of the papers by members of the staff and other research workers which have appeared in the Physical Review, the Proceedings of the National Academy of Sciences and of the American Academy and other periodicals during 1930-31. There are forty of them, which differ considerably in type and area of the letterpress, but are all cut to pages $9 \frac{1}{4}$ in. $\times 6 \frac{3}{4}$ in. Their subjects extend over almost every branch of physics and they testify to the catholicity and quality of the research work done at Harvard. The completion of the new research laboratory and the improvement of the Jefferson Laboratory during the period covered by the volume afford a suitable opportunity for a 47-page illustrated description of the present buildings and equipment, and a short history of their foundation and of the work done in them, and in the Cruft Laboratory. Nearly 130 men have carried on research in the laboratories during the last thirty years and many of them now fill chairs of physics in American universities.

\section{Mining Facilities in South Australia}

According to the annual report of the Director of Mines and Government Geologist of South Australia for 1931, an amending act was passed during the year concerning principally mining upon lands, beneath which mineral substances had been alienated prior to the adoption of the principle of reservation of such substances. The act protects land-owners, but under certain conditions allows prospectors to enter such lands under reasonable conditions; the responsibility for seeing that such an authority is not given to an undesirable character is placed upon the Warden. 